\title{
Rancang Bangun Sistem Irigasi Tanaman Otomatis Menggunakan Wireless Sensor Network
}

\author{
M.Dzulkifli S, Muhammad Rivai, dan Suwito \\ Teknik Elektro, Fakultas Teknologi Industri, Institut Teknologi Sepuluh Nopember (ITS) \\ Jl. Arief Rahman Hakim, Surabaya 60111 Indonesia \\ e-mail:muhammad_rivai@ee.its.ac.id, suwito@ee.its.ac.id
}

\begin{abstract}
Abstrak-Pengairan atau irigasi merupakan faktor penting dalam industri pertanian dan perkebunan. Ancaman serius yang dihadapi industri tersebut adalah semakin menurunnya ketersediaan air. Oleh karena itu dibutuhkan upaya pengelolaan air secara tepat khususnya dalam irigasi. Air yang digunakan untuk irigasi secara konvensional tidak efsien karena memerlukan banyak air dan tidak sesuai kebutuhan. Selain itu, irigasi konvensional memerlukan waktu yang tidak sedikit hanya untuk mengairi tanaman sehingga tidak efektif untuk lahan yang banyak dan relatif luas. Untuk itu maka diperlukan teknologi yang secara otomatis melakukan pengairan yang efektif dan efisien. Wireless Sensor Network (WSN) merupakan suatu sistem komunikasi data nirkabel yang terdiri dari beberapa node yang ditempatkan di area tertentu. WSN ini diimplementasikan ke dalam sistem irigasi otomatis ini untuk memudahan komunikasi data dengan jarak yang jauh. Sistem ini menggunakan sensor Higrometer YL-69, untuk komunikasi wireless menggunakan NRF24L01+, prosessor menggunakan arduino untuk node dan router, dan raspberry pi pada server. Hasil percobaan menunjukkan bahwa NRF24L01+ dapat berkomunikasi antar modul dengan baik pada jarak 35 meter. Frekuensi pada radio yang digunakan sebesar $2.4 \mathrm{GHz}$ dengan kecepatan 2Mbps. Pengaturan delay optimal pada komunikasi pada wireless sensor network menggunakan NRF24L01+ adalah 500 ms. Pengaturan irigasi dengan menggunakan kontrol fuzzy didapatkan kesalahan rata-rata terhadap titik acuan sebesar $11 \%$.
\end{abstract}

Kata Kunci-Irigasi, Wireless Sensor Network, Kontrol Fuzzy.

\section{PENDAHULUAN}

Di negara kita pertanian/perkebunan merupakan sumber utama dalam memenuhi kebutuhan pangan. Di dalam pertanian/perkebunan, air adalah hal yang sangat penting untuk memenuhi kebutuhan tumbuhan. Pengaturan pembagian atau pengaliran air menurut sistem tertentu di sawah/lahan pertanian disebut irigasi. Pengairan atau irigasi merupakan faktor penting dalam industri pertanian dan perkebunan. Irigasi dapat mempengaruhi hasil dari pertanian dan pekebunan apakah produknya baik atau tidak.

Beberapa ancaman serius yang dihadapi industri tersebut salah satunya adalah semakin menurunnya ketersediaan air. Untuk itu dibutuhkan upaya untuk menggunakan air secara tepat. Teknologi pengairan yang masih konvensional belum mampu mengelola air secara tepat. Pada umumnya petani mengunjungi lahannya untuk melihat kelembabapan atau kondisi pada tanah secara periodik dan mengairi lahan pertanian sesuai dengan perspektif petani.
Air yang digunakan untuk pengairan model ini tidak efisien karena memerlukan jumlah yang banyak dan tidak sesuai kebutuhan. Pada umumnya mereka belum memanfaatkan irigasi secara efisien dan efektif. Kebutuhan air di masingmasing lahan berbeda-beda tergantung kondisi lahan, apakah kering, semi kering, lembab atau basah. Kondisi ini mempengaruhi air yang dibutuhkan untuk pengairan lahan tersebut. Selain itu teknologi tersebut masih dilakukan secara manual dan memerlukan waktu yang tidak sedikit hanya untuk mengairi tanaman sehingga tidak efektif. Misalnya para petani harus menunggu untuk mematikan pompa air atau menyiram satu persatu lahan. Untuk lahan yang kecil, pengendalian kebutuhan tanaman (seperti air) secara manual masih dimungkinkan. Tetapi pendekatan itu tidak layak untuk lahan yang lebih luas dan besar. Menyiasati hal tersebut pengelolaan air harus diusahakan secara optimal yaitu tepat waktu, tepat jumlah, dan tepat sasaran, dan juga menjangkau area yang luas sehingga efisien dalam upaya peningkatan produktivitas maupun perluasan areal tanam dan peningkatan intensitas pertanaman.

Untuk mengatasi permasalahan tersebut diatas, maka penulis mempunyai ide untuk merancang dan membuat suatu alat yang dapat mengurangi beberapa kelemahan yang terjadi apabila menggunakan sistem irigasi secara tradisional. Sebuah langkah alternatif untuk menggunakan Wireless Sesnsor Network (WSN) dalam memantau kondisi irigasi suatu lahan. WSN ini diimplementasikan ke dalam sistem irigasi otomatis ini untuk memudahan komunikasi data dengan jarak yang jauh. Pada sistem ini juga akan diberikan sensor Soil Moisture untuk mengukur kelembaban tanah, transceiver dan receiver untuk komunikasi data, Arduino untuk memproses data serta keran sebagai pintu air dan Fuzzy Logic sebagai controller. Dengan menggunakan Sistem irigasi otomatis berbasis Wireless Sensor Network diharapkan dapat mengatasi masalah tersebut serta meningkatkan produksi dan menghemat biaya produksi.

\section{TEORI PENUNJANG}

\section{A. Irigasi}

Menurut peraturan pemerintah No. 23 / 1998 tentang irigasi, bahwa irigasi adalah usaha untuk penyedian dan pengaturan air untuk menunjang pertanian atau perkebunan [1]. Menurut PP No. 22 / 1998 irigasi juga termasuk dalam pengertian Drainase yaitu: mengatur air terlebih dari media tumbuh tanaman atau petak agar tidak mengganggu pertumbuhan maupun produksi tanaman [2]. 
Beberapa jenis irigasi pada gambar 1, antara lain [3]:

1. Irigasi Permukaan (Surface Irigation)

Irigasi Permukaan merupakan jenis irigasi yang mengambil air langsung dari sungai dengan menggunakan saluran/pompa/pipa sehingga air akan meresap sendiri ke poripori tanah. Sistem irigasi ini merupakan sistem irigasi pertama yang digunakan. Sistem irigasi ini masih sangat konvensional, di Indonesia masih banyak dijumpai.

2. Irigasi Bawah permukaan (Sub Surface Irigation)

Sistem irigasi ini mengairi tanaman melewati pipa yang sudah ditanam di zona perakaran. Sehingga air bisa langsung menuju akar tanaman.

\section{Irigasi Pancaran (Sprinkle Irigation)}

Irigasi pancaran adalah irigasi yang menggunakan tekanan untuk menyalurkan air sehingga air yang keluar seperti tetesan hujan yang membasahi pertanian atau taman. Irigasi ini bisa digunakan pada taman-taman. Besar kecilnya pancaran diatur oleh mesin baik manual ataupun otomatis.

\section{Irigasi Tetes (Drip Irigation)}

Sistem irigasi tetes pipa yang dilubangi kecil sehingga air yang keluar dalam bentuk tetesan yang akan langsung menuju tanaman

\section{B. Wireless Sensor}

Wireless Sensor Network (WSN) dalam bahasa Indonesia disebut Jaringan Sensor Nirkabel (JSN). WSN merupakan suatu jaringan nirkabel yang terdiri dari kumpulan node sensor yang tersebar di beberapa area tertentu. Tiap node sensor memiliki kemampuan untuk mengumpulkan data dan informasi yang nantinya akan dikirim ke server/base station [4]. WSN adalah suatu infrastruktur jaringan wireless yang menggunakan sensor untuk memantau kondisi fisik atau kondisi lingkungan yang dapat terhubung ke jaringan. Masing-masing node dalam jaringan sensor nirkabel biasanya dilengkapi dengan radio transceiver atau alat komunikasi wireless lainnya, mikrokontroler, dan sumber energi yang biasanya adalah baterai.

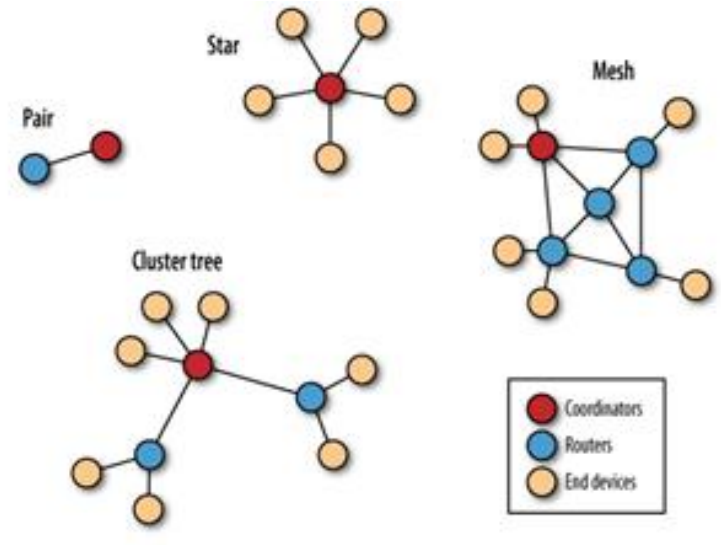

Gambar 1 Topologi Wireless Sensor Network

Pada dasarnya wireless sensor network memiliki suatu tujuan yaitu untuk melakukan suatu hal yang spesifik [5]. Berbeda dengan jaringan konvensional yang tujuanya melakukan sesuatu yang lebih general dan dapat melayani banyak pengaplikasian. Dalam prosesnya wireless sensor network memiliki karakter tersendiri dibanding jaringan yang lain.
Hal yang paling diperhatikan pada wireless sensor network adalah konsumsi daya [6]. Karena desain pada wireless sensor network terdiri dari banyak node sensor ataupun node koordinator. Pada umumnya suatu sistem jaringan lebih mengutamakan performa. Namun pada wireless sensor network lebih mengutamakan konsumsi daya rendah. Hal ini dikarenakan dalam suatu jaringan (network) diharapkan dapat bekerja dalam waktu yang lama.

Dalam penerapan wireless sensor network di lapangan terdapat beberapa topologi jaringan, seperti pair, point to point, star, mesh, dan cluster tree [7].

\section{Sensor Higrometer Soil Moisture YL-69}

Sensor Higrometer merupakan sensor yang mengimplementasikan prinsip kerja sensor resistif. Sensor ini terdiri dari dua elektrode yang nantinya akan membaca kelembaban didaerah sekitarnya, sehingga arus melewati dari satu elektrode ke elektrode yang lain. Besar nilai arus dipengaruhi oleh besar kecilnya resistansi akibat kembaban yang berada disekitar elektrode. Jika resistansi besar maka kelembaban dari tanah kecil, sedangkan jika resistansi kecil maka arus yang melewati elektrode semakin banyak dan menunjukkan bahwa kelembababan tinggi.

Sensor Higrometer YL-69 dapat mengukur kelembapan tanah pada area yang tidak terlalu luas [8]. Oleh karena itu penempatan sensor harus tepat agar bisa pembacaan sensor maksimal.

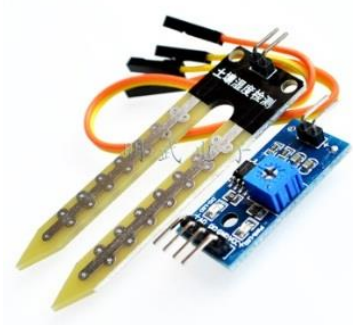

Gambar 2 Sensor Higrometer Soil moisture YL-69

\section{Arduino Uno}

Arduino Uno adalah salah satu produk berlabel arduino yang sebenarnya adalah suatu papan elektronik yang mengandung mikrokontroler ATMega328 (sebuah keping yang secara fungsional bertindak seperti sebuah komputer) [9]. Piranti ini dapat dimanfaatkan untuk mewujudkan rangkaian elektronik dari yang sederhana hingga yang kompleks. Pengendalian LED hingga pengontrolan robot dapat diimplementasikan dengan menggunakan papan berukuran relatif kecil. Modul arduino uno bisa dilihat pada gambar 4.

\section{E. Tranceiver NRF24LO1+}

NRF24L01+ merupakan sebuah modul komunikasi yang dapat dan menerima data secara half duplex. Frekuensi yang digunakan modul ini adalah $2.4 \mathrm{GHz}$. Untuk dapat mengirim dan menerima data, modul ini harus diberikan sebuah alamat (address) untuk dirinya dan tujuan. Transceiver ini sangat powerfull karena bisa menerima data dari banyak node yang alamat tujuannya sama.

Menurut datasheet, jarak yang bisa ditempuh untuk komunikasi antar NRF24L01+ sebesar 500 feet atau jika dikonversi ke meter menjadi 152 meter. Kecepatan pengiriman 
pada modul ini bervariasi bisa diatur sesuai yang diinginkan. Beberapa diantaranya adalah 250Kbps, $1 \mathrm{Mbps}$, dan $2 \mathrm{Mbps}$ [10].

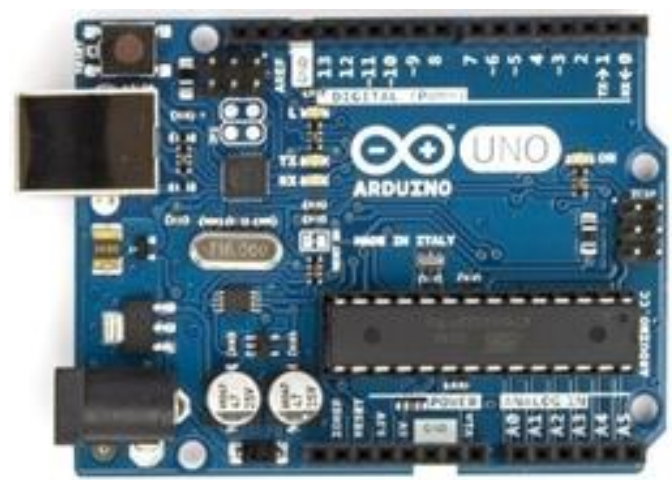

Gambar 3 Arduino Uno

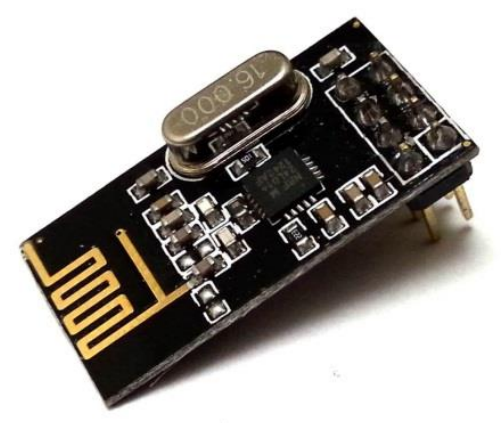

Gambar 4 NRF24L01+

\section{F. Kontrol Fuzzy}

Kontrol yang digunakan pada sistem ini adalah dengan menggunakan fuzzy. Pada fuzzy ada beberapa tahapan yaitu Fuzzifikasi, Rule base, Defuzzifikasi. Fuzzifikasi adalah proses pengubahan nilai dari numerik menjadi linguistik, seperti panas, dingin, dan lembab. Kontrol fuzzy sangat dipengaruhi oleh rule base yang sudah didesain. Ada beberapa metode yang digunakan diantaranya yaitu, Sugeno dan Mamdani. Blok diagram pada kontrol fuzzy bisa dilihat pada gambar 6 .

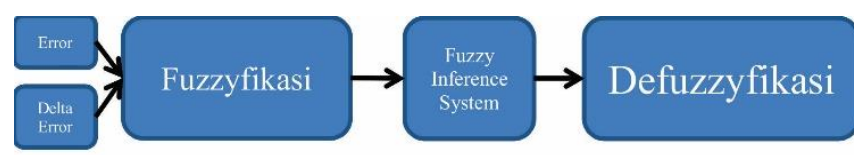

Gambar 6 Blok diagram kontrol fuzzy

\section{PERANCANGAN SISTEM}

Pembuatan sistem pada penelitian ini secara garis besar terbagi menjadi 3 sub sistem utama, yang pertama adalah Node, Router dan Server. Node sensor berfungsi untuk mengirim data sensor ke router. Pada penelitian ini nilai sensor yang dikirim adalah sensor kelembaban. Selain itu node sensor digunakan untuk mengatur putaran keran air menggunakan kontrol fuzzy. Router berfungsi untuk menerima dan mengirim data dari node ke server. Server pada sistem ini berfungsi untuk menerima data dan menampilkan data kelembaban dari node melalui router. Data ditampilkan dalam bentuk sebuah website yang bisa diakses secara online. Untuk diagram blok secara keseluruhan dari sistem ini bisa dilihat pada gambar 7 .

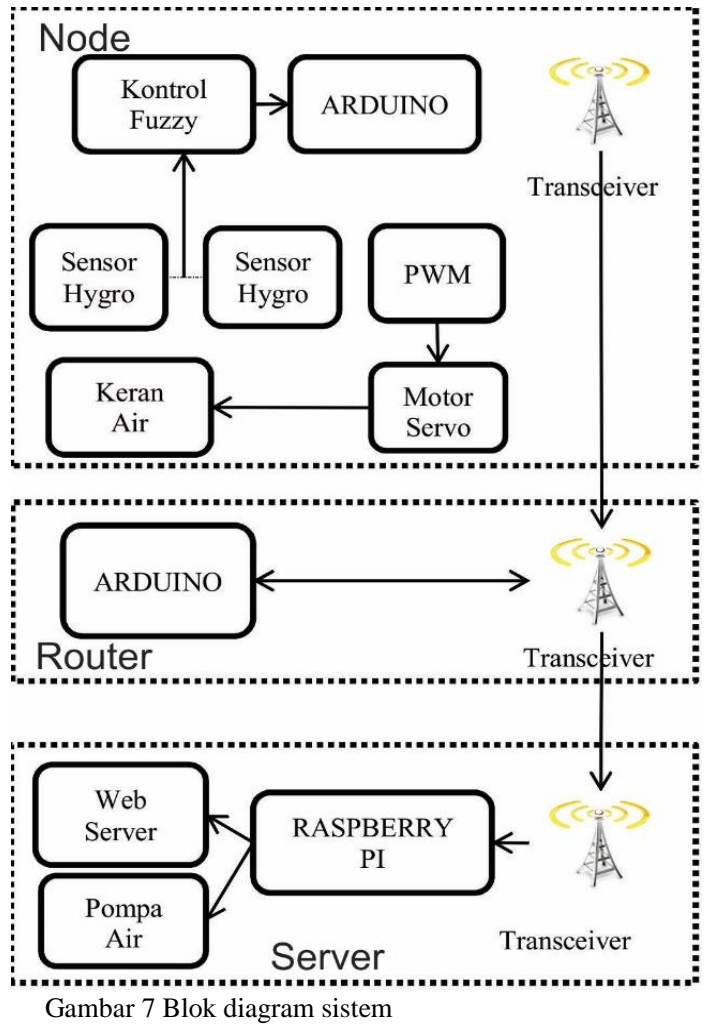

\section{A. Perancangan Node sensor}

Perangkat keras yang digunakan dalam node sensor adalah motor servo, Arduino Uno, sensor higrometer soil moisture YL69, dan NRF24L01+. Arduino Uno pada node sensor berfungsi untuk mengolah data dari sensor untuk dijadikan input pada kontrol fuzzy. Selain itu juga berfungsi untuk mengatur dan mengontrol komunikasi data antara node dengan router.

Hasil dari output fuzzy adalah besaran sudut dari keran dengan mengatur besaran nilai PWM yang sudah dikonversi ke dalam satuan sudut. Diagram alir node dapat dilihat pada gambar 8 .
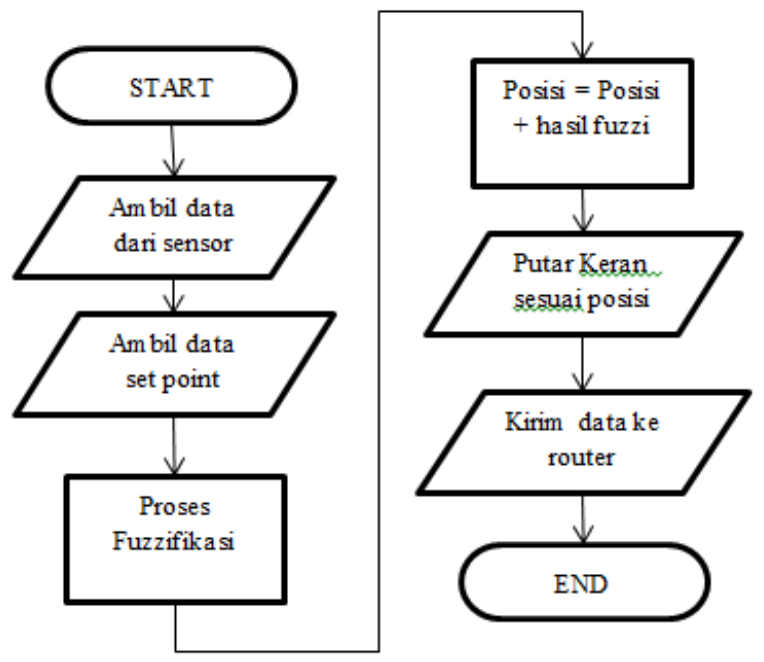

Gambar 8 Diagram alir node

\section{B. Perancangan Router}

Perangkat keras yang digunakan dalam router terdiri dari arduino uno dan transceiver. Tugas router hanya menerima dan 
mengirim informasi baik dari node ke server atau dari server ke node. Diagram alir router bisa dilihat pada gambar 9.

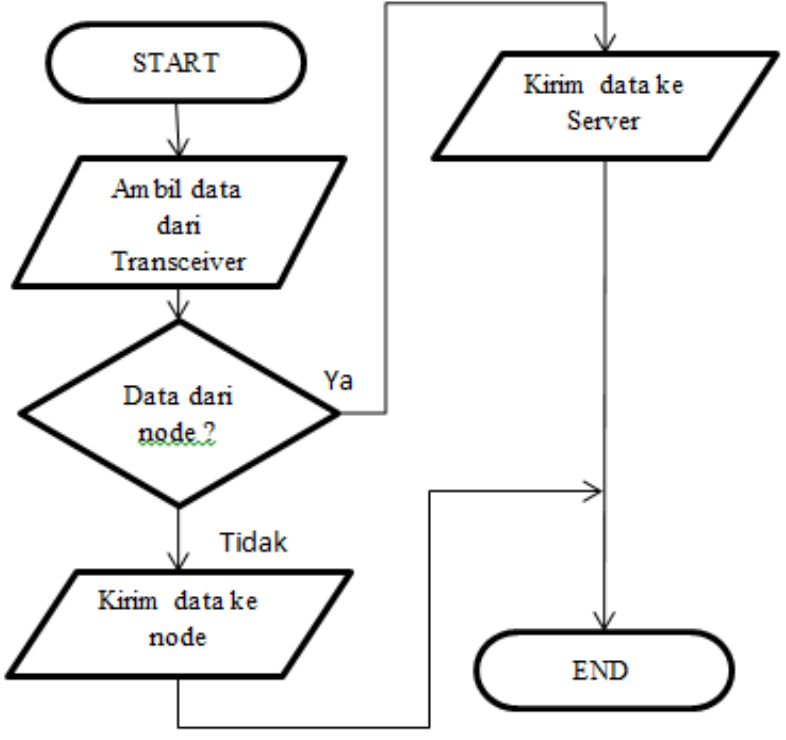

Gambar 9 Diagram alir router

\section{Perancangan Server}

Perangkat keras pada server terdiri dari Tranceiver NRF24L01+, Raspberry pi dan pompa Air. Pada server terdapat satu sensor sebagai indikator air pada sumber (tendon). Jika air kurang dari ukuran tertentu maka akan mematikan pompa air secara otomatis. Hal ini agar pompa tidak menyala jika air dalam keadaan habis. Pompa yang menyala secara terus menerus ketika air dalam keadaan kosong dapat menyebabkan pompa air cepat rusak. Diagram alir server bisa dilihat pada gambar 10 .

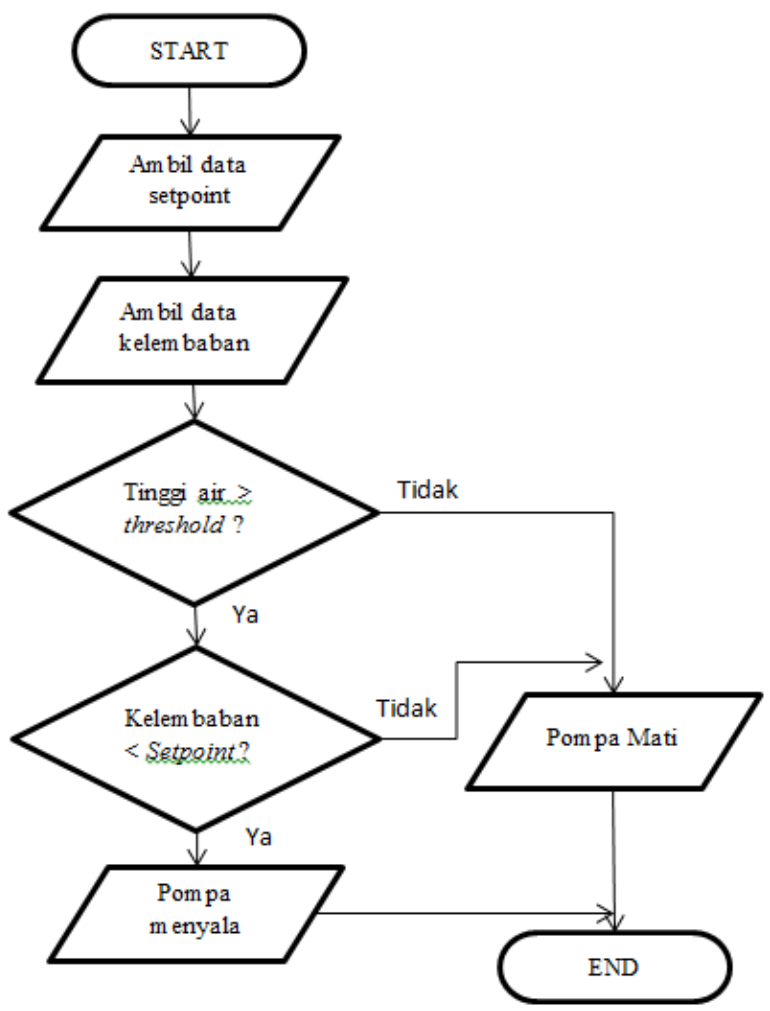

Gambar 10 Diagram alir server

\section{Perancangan Prototipe Lahan}

Perancangan prototipe lahan menggunakan kotak kayu persegi yang mempunyai ukuran panjang $60 \mathrm{~cm}$ lebar $60 \mathrm{~cm}$ dan tinggi $17 \mathrm{~cm}$. Prototipe tersebut terdapat 2 selang yang digunakan untuk mendistribusikan air. Prototipe ini mempunyai satu kotak kecil yang digunakan sebagai tempat processor, motor servo, dan keran air. Suplai daya pada node sensor menggunakan powerbank dengan solar cell dengan kapasitas 6900 mAH. Prototipe bisa dilihat pada gambar 11.

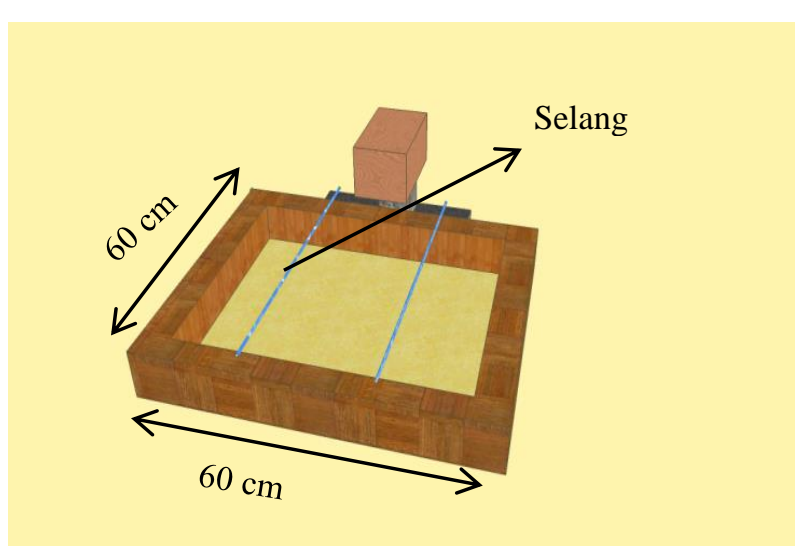

Gambar 11 Perancangan prototipe lahan

\section{IMPEMENTASI, PENGUJIAN DAN ANALISA}

Pada tahap ini yaitu membahas tentang implementasi, pengujian sistem dan analisis data. Pengujian sistem akan disertai hasil dan gambar pendukung.

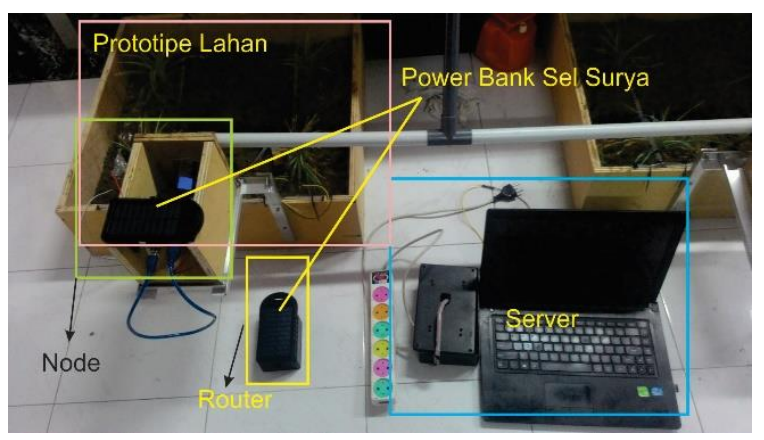

Gambar 12 Implementasi sistem

\section{A. Implementasi Alat}

Realisasi dari desain yang telah dibuat dapat dilihat pada gambar 12. Keran air yang digunakan pada aktuator yaitu menggunakan keran air yang berputar 90 derajat. Untuk itu nantinya dilakukan kalibrasi antara keran air dan motor servo. Pasir yang digunakan pada prototipe lahan berupa pasir merah halus tanpa kerikil dengan ketinggian $8 \mathrm{~cm}$. Selang air yang digunakan pada penelitian ini adalah selang air dengan ukuran diameter sebesar $9 \mathrm{~mm}$ sebanyak 2 buah. Selang air akan dilubangi dengan jarak antaar lubang sebesar $2 \mathrm{~cm}$.

\section{B. Pengujian Komunikasi NRF24L01+}

Pengujian pada Komunikasi Wireless dilakukan dengan cara mengirimkan 100 paket pada jarak pengujian mulai dari 0-60 meter. Modul NRF24L01+ yang digunakan tanpa antena LNA 
dan diletakkan pada ketinggian 1,5 meter. Pengujian dilakukan di area terbuka tanpa halangan.

Dari hasil pengujian yang telah dilakukan (gambar 13) data yang terkirim pada jarak 0-35 meter dapat menerima kesulurah paket data tanpa kehilangan satupun. Pada jarak 40 NRF24L01+ mampu menerima data dengan loss sebesar 5\% . Pengiriman paket data pada jarak 45 meter mulai mengalami loss yang cukup banyak yaitu sebesar $20 \%$ pada jarak 55 meter NRF24L01+ masih dapat menerima data dengan presentase 70\%. Komunikasi mengalami loss $100 \%$ pada jarak 60 meter. Dari data diatas bisa disimpulkan bahwa komuikasi NRF24L01+ optimal dengan jarak 35 meter.

\section{Hubungan tegangan dengan kelembaban (\%)}

Satuan standar yang digunakan untuk mengukur kelembaban adalah moisture (kelembaban tanah) dalam persen (\%). Oleh karena itu perlu pengkonversian nilai dari tegangan ke dalam satuan moisture. Untuk itu dilakukan pengujian menggunakan tanah berdasarkan jumlah air yang diberikan dalam satuan $\mathrm{mL}$.

Dari data pengujian pada gambar 14 bisa dilihat bahwa hasil dari pengujian mendekati linear. Dengan menggunakan rumus dibawah ini.

$$
\frac{x-x_{1}}{x_{2}-x_{1}}=\frac{y-y_{1}}{y_{2}-y_{1}}
$$

Maka diperoleh formula untuk mengubah nilai tegangan ke kelembaban (\%) sebagai berikut

$$
y=\left(\frac{x-0.174}{3.006}\right) \times 100 \%
$$

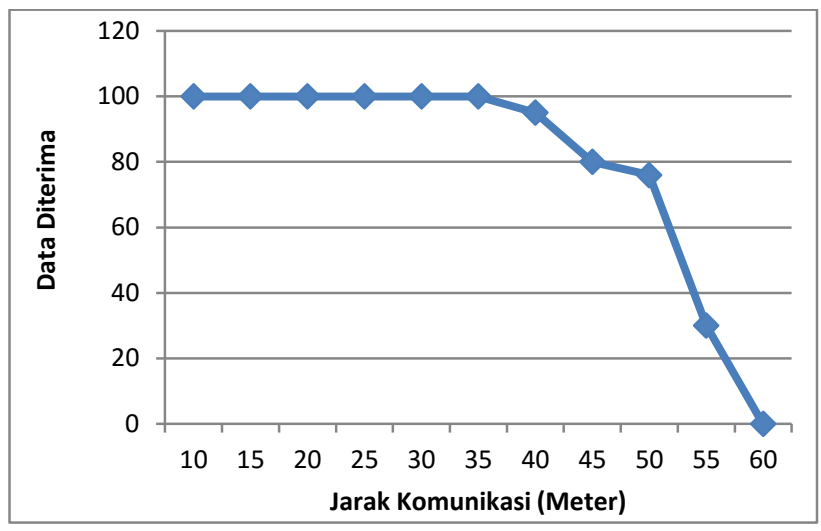

Gambar 13 Grafik pengujian jarak komunikasi

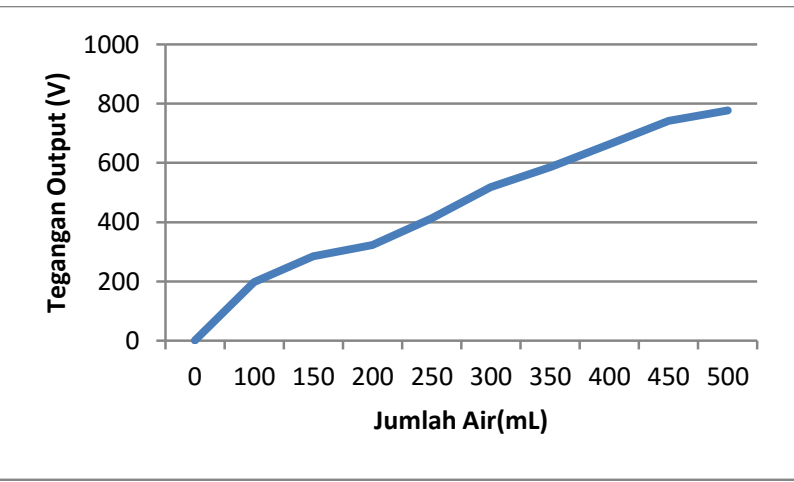

Gambar 14 Grafik pengukuran kelembaban terhadap air
Dari rumus (2) bisa digunakan untuk mengkonversi nilai tegangan kedalam bentuk persen. Misalnya pada sensor ouput yang keluar adalah tegangan dengan nilai sebesar 1.24 V. Maka nilai kelembabannya adalah sebesar $35.42 \%$.

\section{Pengujian Kontrol Fuzzy pada keran Air}

Pengujian pada tahap ini dilakukan dengan 2 kali pengujian dengan set poin yang sama setiap pengujianya.

Tabel 1

Pengujian ke-1 kontrol fuzzy

\begin{tabular}{|c|c|c|c|c|}
\hline $\begin{array}{c}\text { Set Point } \\
(\%)\end{array}$ & $\begin{array}{c}\text { Sensor 1 } \\
(\%)\end{array}$ & $\begin{array}{c}\text { Sensor 2 } \\
(\%)\end{array}$ & $\begin{array}{c}\text { Rata-rata } \\
\text { Sensor (\%) }\end{array}$ & Offset (\%) \\
\hline & & & & \\
\hline 33 & 48.61 & 48.09 & 48.37 & 9.71 \\
\hline 58 & 75.53 & 77.34 & 76.44 & 12.03 \\
\hline 71 & 82.1 & 86.22 & 84.16 & 6.88 \\
\hline
\end{tabular}

Tabel 2

Pengujian Ke-2 kontrol fuzzy

\begin{tabular}{|c|c|c|c|c|}
\hline $\begin{array}{c}\text { Set Point } \\
(\%)\end{array}$ & $\begin{array}{c}\text { Sensor 1 } \\
(\%)\end{array}$ & $\begin{array}{c}\text { Sensor 2 } \\
(\%)\end{array}$ & $\begin{array}{c}\text { Rata-rata } \\
\text { Sensor (\%) }\end{array}$ & Offset (\%) \\
\hline & & & & \\
\hline 33 & 49.64 & 46.68 & 48.16 & 9.52 \\
\hline 58 & 71.93 & 73.6 & 72.76 & 8.36 \\
\hline 71 & 78.24 & 83.39 & 80.81 & 3.53 \\
\hline
\end{tabular}

Tabel 3

Pengujian sistem terhadap setpoint

\begin{tabular}{|c|c|c|c|c|}
\hline $\begin{array}{c}\text { Set Point } \\
(\%)\end{array}$ & $\begin{array}{c}\text { Sensor 1 } \\
(\%)\end{array}$ & $\begin{array}{c}\text { Sensor 2 } \\
(\%)\end{array}$ & $\begin{array}{c}\text { Rata-rata } \\
(\%)\end{array}$ & Error (\%) \\
\hline \hline 33 & 36.25 & 37.66 & 36.95 & 9.83 \\
\hline 46 & 45.78 & 51.06 & 48.42 & 6.17 \\
\hline 58 & 62.78 & 64.07 & 63.44 & 11.67 \\
\hline 71 & 76.95 & 79.27 & 78.11 & 16.33 \\
\hline
\end{tabular}

Dari tabel 1 dan 2 didapat bahwa terdapat offset pada pembacaan sensor. Rata-rata offset dari data diatas sebesar $8.29 \%$ dan error rata-ratanya sebesar $25.43 \%$ sehingga pengujian berikutnya adalah pengujian sistem dengan ditambahkan offset dari pengujian sebelumnya.

Offset pada penelitian ini adalah jumlah air sisa yang berada pada selang ketika keran sudah tertutup penuh. Oleh karena itu untuk menghilangkan kerugian hal tersebut maka kontrol fuzzy pada sistem ini harus dikompensasi sebesar nilai offset.

Pengujian selanjutnya adalah pengujian kontrol fuzzy dengan menggunakan offset dari pengujian sebelumnya. Pada tabel 3 bisa dilihat bahwa set point $33 \%$ dengan nilai pada sensor 1 sebesar $36.249 \%$ dan sensor 2 sebesar 37.66583\%. Dari set point tersebut didapat error sebesar 9.833\%. Pada set point 46 didapat nilai kelembaban pada sensor 1 sebesar $45.78 \%$ sedangkan pada sensor 2 sebesar $51.06 \%$. Didapat error pada set point tersebut sebesar $6.167 \%$. \% . Pada set point $58 \%$ didapat nilai kelembaban pada sensor 1 sebesar $62.78 \%$ sedangkan pada sensor 2 sebesar $64.07 \%$. Didapat error pada set point tersebut sebesar $11.667 \%$. Pada set point $71 \%$ didapat 
nilai kelembaban pada sensor 1 sebesar $76.95 \%$ sedangkan pada sensor 2 sebesar $79.07 \%$. Didapat error pada set point tersebut sebesar $16.337 \%$. Dari kesemua data yang diperoleh, error rata-rata terhadap set point pada sistem ini adalah sebesar $11 \%$

Dari data diatas dapat dilihat bahwa offset yang ditambahkan pada kontrol dapat menurunkan error dengan sangat baik. Error yang didapat pada pengujian sebelumnya turun sekitar $14.53 \%$

\section{KESIMPULAN}

Telah dibuat sebuah sistem irigasi tanaman otomatis menggunakan wireless sensor network dengan 2 node, 1 router dan 1 server yang dapat berkomunikasi antar modul dengan baik pada jarak 35 meter. Frekuensi pada radio yang digunakan sebesar $2.4 \mathrm{GHz}$ dengan kecepatan 2Mbps. Wireless dengan menggunakan NRF24L01+. Pengaturan delay pada modul tersebut sangat berpengaruh dimana besar delay harus sama dengan pengirim sehingga terjadi sinkronisasi. Pada penelitian ini delay yang optimal digunakan sebesar $500 \mathrm{~ms}$. Pengujian sensor higrometer didapatkan nilai pada tanah kering sebesar $0.174 \mathrm{~V}$, sedangkan untuk tanah berkadar air tinggi output pada sensor memiliki nilai sebesar 3.184 V. Pengujian sistem dilakukan dengan 2 kali pengujian yang pertama tanpa menggunakan offset dan yang kedua menggunakan offset. Pengujian yang pertama didapat error rata-rata kontrol fuzzy terhadap titik acuan sebesar $25 \%$, sedangkan pada percobaan kedua dengan menggunakan offset rata-rata error kontrol fuzzy terhadap titik acuan sebesar $11 \%$.

\section{DAFTAR PUSTAKA}

[1] Peraturan Pemerintah No. 23/1998, Tentang Irigasi, 1998

[2] Peraturan Pemerintah No. 22 / 1998 tentang tata pengaturan air, 1998

[3] Chandan, Pramitee, "A Low Cost Smart Irrigation Control System" in : IEEE sponsored $2^{\text {nd }}$ international conference on electronics and communication system

[4] Dargie Waltenegus and Peullabauer Christian, "Fundamentals of Wireless Sensor Network." 2010

[5] Chunlong Zhang, Min Zhang, 2012 " Smart Home Design based on ZigBee Wireless Sensor Network" in: 7th International ICST Conference on Communications and Networking in China (CHINACOM)

[6] "IEEE 802.11: Wireless LAN Medium Acces Control (MAC) and Physical layer(PHY) Spesification “ 2012

[7] Guoqing Dang, Xiaoyan Cheng, 2014 . Applicaton of Wireless Sensor Network Based Zigbee. In: IEEE Workshop on Advanced Research and Thecnology in Industry Application (WARTIA)

[8] Datasheet Sensor Hygtometer Soil Moisture YL-69 http://zone.ni.com/devzone/cda/tut/p/id/7142

[9] Arduino.co

[10] __,Nordic Semiconductor NRF24L01+ product specification.pdf" 3 februari 2016.https://www.nordicsemi. >chi>file 